\title{
Kerkgeskiedskrywing: Hoe skryf ons kerkgeskiedenis?
}

\author{
A D Pont \\ Emeritus-professor: Departement Kerkgeskiedenis en Kerkreg (Afd A) \\ Universiteit van Pretoria
}

\begin{abstract}
On writing church history

Every generation writes its own history of the Church. As the past is continually evaluated from different points of view and as every generation asks new questions, so the understanding of the past changes and history is rewritten. In discussing this situation, three issues are treated: the understanding of the past and what history is, the requirements for writing history and the question whether history has a vision for the future. These matters continually appear in discussions on history and the requirements for writing history.
\end{abstract}

\section{INLEIDING}

Die opgawe om oor kerkgeskiedskrywing te praat en om terselfdertyd 'n tydsbeperking daarop te plaas kan, met die eerste opslag, as 'n onvriendelike versoek verstaan word. Aan die ander kant is dit ook 'n verérende opdrag omdat miskien geoordeel is dat dit moontlik is om in 'n beperkte tyd tog iets sinvols te sê. Dit vanweë die feit dat die vrae rondom die geskiedenis, die skrywe daarvan en die moontlike duiding van die geskiedenis, so omvangryk is en dit terselfdertyd ' $n$ terrein is waaroor daar baie verskillende standpunte bestaan 1 .

Tog word 'n sekere koers deur die opdrag bepaal wat aangedui word deur die vraag: Hoe skryf ons kerkgeskiedenis? In verskillende opsigte is dit 'n vraag wat voortdurend na vore kom omdat elke geslag ander vrae aan die verlede stel. Dikwels bepaal die vraag dan die koers van die antwoord. Daarom bly die geskiedskrywers besig, besig met die verlede en die navorsing van die bronne waarmee 'n beeld van die verlede geteken kan word. Dit is natuurlik so dat die verlede nie 'n eie stem het nie en alleen deur die arbeid van die geskiedskrywer aan die woord kom. Daarom hang so baie af van die beeld wat die geskiedskrywer van die verlede gee hoe die stem of voorbeeld van die verlede in die hede gehoor word en hoe dit die toekoms rig. Want die

* Referaat gelewer op 26 Augustus 1997 tydens die kongres van die Kerkhistoriese Genootskap van die Nederduitsch Hervormde Kerk van Afrika, op die kampus van die Universiteit van Pretoria. 
verlede is wel ' $n$ voltooide, afgehandelde saak wat nie weer herhaal kan word nie, maar die verstaan en die interpretasie van die gebeure van die verlede in die hede hét ' $n$ invloed sowel in die hede as vir die toekoms. Daarom is die geskiedskrywing nooit klaar met die verlede nie. Dit blyk, om maar ' $n$ voorbeeld te noem, uit die nuwe belangstelling wat in ons dae bestaan vir die lewe en werk van Johannes Calvyn. Dit het nie alleen reeds gelei tot ' $n$ hernude ontginning van die bronne-materiaal nie maar ook tot die begin van 'n nuwe, omvattende en kritiese uitgawe van al sy gepubliseerde werk.

Maar ook in ons tyd en situasie is die vraag: Hoe skryf ons kerkgeskiedenis? van belang want soos die tyd verbygaan, is daar in ons kerklike kring al meer 'n behoefte aan die optekening van die geskiedenis van gemeentes en van ander kerklike gebeure wat alweer so ver agter ons tyd lê dat die huidige geslag dit nie meer uit eie ervaring of kennis ken nie. Daarby word die naderende koms van die jaar 2000 skynbaar aangevoel as ' $n$ bepaalde eindpunt én nuwe begin en ontstaan die vraag na 'n nuwe geskiedenis van ons kerk gedurende die afgelope eeu. Daarom alleen al is dit van 'n belang om 'n oomblik die vraag na die skrywe van geskiedenis te stel en te bespreek.

Om enigermate oorsigtelik te bly, kan die vraag na die skryf van die kerkgeskiedenis uiteenval in drie dele: die verstaan van die geskiedenis, die skryf van die geskiedenis en dan die duiding van die geskiedenis.

\section{OOR DIE VERSTAAN VAN DIE BEGRIP KERKGESKIEDENIS}

Die eerste saak wat hier na vore kom is die vraag wat onder die begrip geskiedenis verstaan word. Merkwaardig genoeg is die omskrywing van die begrip baie meer omstrede as wat van so 'n vanselfsprekende woord verwag word ${ }^{2}$. Terwyl dit hier in hoofsaak om kerkgeskiedenis gaan, kan aanvanklik gestel word dat dit in die geskiedenis gaan om die mens, kollektief gesproke, sy dade en beslissings in die verlede wat nou nie meer uitwisbaar of veranderbaar is nie. Maar dan is nie alles wat gedoen en gesê en besluit is sondermeer geskiedenis nie. 'Die gebeure uit die gister van die mensbestaan, word eers geskiedenis indien daar ' $n$ verband kom tussen daardie gebeurtenisse en ons wat vandag lewe' (Pont 1958:3). So gesien is die geskiedenis die verhaal van menslike handelinge in die verlede wat in die hede deurwerk. 'n Voorbeeld daarvan is Martin Luther se publikasie van sy 95 Stellings in Wittenberg op 31 Oktober 1517 of die besluite van die eerste twee Algemene Kerkvergaderings van ons kerk wat in 1853 gehou is.

Wat die kerkgeskiedenis betref kom daar nog iets by aangesien die kerk meer is as net 'n kultuur of sosiologiese verskynsel. Die kerk wat in die Nuwe Testament aangedui word as die volk van God of die gemeente of as Israel en selfs as 'n gemenebes (Fil $3: 20$ ) word in die NGB, artikel 27 aangedui as '...'n heilige vergadering van almal wat 
waarlik in Christus glo, wat almal hulle volle saligheid in Jesus Christus verwag en in sy bloed gewas is, geheilig en verseël deur die Heilige Gees'. Daar kom dus by die kerk as menslike gemeenskap 'n vertikale dimensie. Schmidt (1954:1-2) stel dat aangesien die kerk in die Nuwe Testament aangedui word as die liggaam waarvan die Here Jesus Christus die enige hoof is, is die kerkgeskiedenis ook die geskiedenis van Jesus Christus wat deur middel van die kerk ook in die wêreld werksaam bly ${ }^{3}$. Die een middel waardeur Jesus Christus sy liggaam gebruik om in die geskiedenis van die mens werksaam te bly, is die prediking van die evangelie waardeur mense die geloof ontvang en deel word van sy liggaam wat op pad is na die wederkoms van die Here. Immers in die prediking gaan dit om Jesus Christus, die enige Seun van God in wie en deur wie die ewige en lewende God Hom openbaar. Daardie prediking praat van Jesus Christus wat in die mensegeskiedenis gebore is, in die tyd, 'onder Pontius Pilatus' gekruisig is en fisies weer opgestaan het uit die dood. Dit is Hy wat die koninkryk van God op aarde gevestig het en wat dié ryk in sy volle sigbaarheid sal laat kom as $\mathrm{Hy}$ as wêreldregter terugkeer en 'n einde aan hierdie hemel en aarde sal maak. Hendrikus Berkhof vat dit só saam4: 'De nieuwe Heer brengt geschiedenis in de wereld. Sinsdien zien we ons zelf op weg naar een doel. Het bestaande valt niet samen met het bedoelde. Het leven krijgt de gestalte van doelgericht streven.'

So gesien verloop die geskiedenis van kerk en wêreld tussen die twee groot werklikhede: die lewe van Jesus Christus, die Here, op aarde én die vaste belofte dat Hy weer sal terugkom soos Hy opgevaar het (Hand 1:11). Dit gee aan die geskiedenis 'n vaste lyn vanuit die verlede, deur die hede na die toekoms en gee aan die kerk 'n doelwit wat anderkant hierdie wêreld lê en waaraan die kerk, dit wil sê: die gelowiges, voortdurend deur die prediking van die evangelie, herinner word.

Nou is dit so dat net soos Jesus in 'n verborge gestalte in die wêreld teenwoordig was (vgl Joh 1:10-11) so is ook die kerk, as liggaam van Christus, as werktuig van Christus in 'n verborge gestalte in die wêreld. Want dit is nie vir almal, altyd openlik sigbaar dat die kerk as gemeenskap van gelowiges inderdaad ó́k die liggaam van Christus is nie.

So gesien is die geskiedenis van die kerk, op die oog af, niks meer as die geskiedenis van 'n gemeenskap van mense nie. Tog word die kerk, soos hy is, nie net bepaal deur die wêreld waarin die kerk leef en werk nie maar veral deur die verbondenheid van die kerk met sy enige hoof. Dit bly egter waar dat soos Jesus Christus mens geword het in die geslag van Dawid, so staan die kerk ook nie los en verwyderd van die volk in wie se midde hy leef nie. Die kerk word óók mede-bepaal deur die gelowiges wat die kerk is. Dit is een van die werklikhede waarmee rekening gehou moet word en verklaar waarom die gang van die kerk deur die tyd nie 'n onafgebroke triomftog is 
nie. Die moontlikheid is altyd daar dat die mense in die kerk van mening is dat hulle eie mening belangriker is as die gehoorsaamheid aan God en sy Woord. Maar dit kan ook nie anders nie want indien die kerk, die gemeenskap van die gelowiges, hom sou wou onttrek uit die volk en die wêreld waarin hy geplant is, dan verloën die kerk juis God wat terwille van die mens vlees geword het en verval daarmee in 'n soort docetisme. Die kerk, die geroepe volk van God, is eiesoortig in die breë wêreldgeskiedenis omdat hierdie gemenebes-van-gelowiges ook 'n middel is waardeur God die gang van die geskiedenis bepaal ${ }^{5}$.

As dit gesê word, word dit duidelik dat die gelowiges, die kerk, ingetrek word in die voortgaande stryd wat die magte van die duisternis teen die koninkryk van God voer. Dit is ' $n$ veeleisende stryd want dit gaan om die geloof in en die gehoorsaamheid aan God, die lewe as volk van God op aarde tot eer van God en aan die ander kant die ontkenning van en die opstand teen God, wat baie naby aan die gelowige as sondaar is. In hierdie botsing is die gelowige sowel 'n instrument as 'n medewerker van God in die uitvoering van God se plan met die wèreld ${ }^{6}$. So gesien is die geskiedenis van kerk en wêreld die beskrywing van God se bepaling van die verloop van gebeure op pad na die finale voltooiing. Dit geskied egter nie sonder die spanning wat daar is tussen wat God wil en wat die mens, dikwels in sy eiegeregtigheid, vir homself as ideaal gestel het nie. So is kerkgeskiedenis nie net die sorgvuldige optekening van die geskiedenis van die kerk as 'n menslike gemeenskap nie maar dit gaan ook daarom dat die werk van Jesus Christus, die hoof van die kerk, in die wêreld na vore sal kom. Met ander woorde die kerk kan in sy geskiedenis nooit verstaan word as 'n een-dimensionele, suiwer menslike struktuur nie. Die kerk is meer as die $19 \mathrm{e}$ eeuse omskrywing waar die kerk verstaan is as 'n organisasie vir die instandhouding van die openbare erediens van die Voorsienigheid.

As die geskiedenis so verstaan word as die verhaal van die gebeure tussen die koms en die wederkoms van Christus soos dit ontwikkel in die spanning tussen God se bepaling van die rigting van die geskiedenis en die mens en die kerk se doenighede in ooreenstemming of in stryd met God se wil, dan is dit duidelik dat vir die verstaan van die geskiedenis die geloof in God Drie-enig 'n voorwaarde is. Hierdie verstaan van die geskiedenis is anders as die rasionalistiese verstaan van die geskiedenis wat dikwels as 'wetenskaplik' aangedui word'. Tog is dit so dat die stelling dat die geloof in die Drieenige God die voorwaarde is vir die verstaan van wat geskiedenis is en hoe die geskiedenis verstaan moet word, altyd bevraagteken sal word sowel binne as buite die kerk. Hoewel daarmee rekening gehou kan word, hoef dit nie die kerkgeskiedenisskrywer te intimideer omdat sy verstaan van die geskiedenis én die duiding daarvan deur die geloof bepaal word nie (Pont 1963:151-152). 


\section{HOE SKRYF ONS KERKGESKIEDENIS?}

Wanneer die vraag nou gestel word hóe die geskiedenis geskryf moet word, dan is die eerste antwoord dat dit die optekening is van die gebeure in hulle samehang soos dit in die verlede plaasgevind het. Uit die aard van die saak is die verlede nie meer beskikbaar vir direkte waarneming nie en bestaan daar van die verlede ook nie 'n volledige nalatenskap nie. Daar is egter wel oorblyfsels van die verbygegane tyd: gebruiksvoorwerpe, werktuie, geboue, ruïnes, skilderye, kerkhowe en dergelike meer wat 'n bron van kennis is en kan wees. Met behulp van hierdie soort oorblyfsels kan 'n beeld gevorm word van die middele en moontlikhede wat op 'n gegewe tyd beskikbaar was. Daaruit kan die geskiedskrywer 'n beeld van die mense en hulle tyd vorm en daaruit verskillende afleidings maak.

Daarby kom 'n verdere nalatenskap wat oorleweringe genoem kan word: dokumente, geskrifte, inskripsies, mondelinge getuienis en dergelike meer wat, indien daar ook oorblyfsels is, kan bydra om die kennis van die verlede verder te verbreed. As dit gestel word, is dit duidelik dat die kennis van die verlede, ook bepaal word deur die beskikbare materiaal waarmee 'n beeld van die verlede gerekonstrueer kan word. Hier kan dan daarop gewys word dat geskiedenis, in 'n sekere sin, nie die bestudering van die verlede is nie, maar die studie, in die hede, van die oorblyfsels van die verlede. Die kritiese element wat die kennis van die verlede bepaal is die feitlike gegewens van die verlede wat vandag nog vir studie beskikbaar is. Die verlede kan alleen na waarheid in die hede gerekonstrueer word met daardie vasstaande getuienis wat in die hede beskikbaar is. Dit is waar: geskiedenis is slegs gelyk aan sy getuienis, sy vaste bronne. Basies gaan dit dus in die geskiedenis om 'n soektog na die waarheid en die waarheid berus op die volle spektrum van gekontroleerde, vasstaande feite en nie op spekulasie, versinsels of teorieë nie. So gesien is geskiedenis 'n soektog na verifieerbare feite om daarmee die geskiedenis te bou. Hier lê dikwels 'n 'versoeking' vir die geskiedskrywer om juis, vanweë min of geen feite in 'n bepaalde periode, sy eie mening as 'n historiese feitlikheid aan te bied. Maar dan is die grense van wat geskiedenis is, reeds oor- . skry.

Dit dui op die verantwoordelikheid van die geskiedskrywer-navorser om steeds besig te wees om soveel as moontlik materiaal te bekom om die verlede te kan rekonstrueer. Te dikwels blyk dit dat 'n geskiedskrywer se werk op gebrekkige, onvolledige en onvoldoende bronnestudie berus sodat sy rekonstruksie van die verlede minder. bruikbaar is.

Dit is egter ook waar dat die geskiedskrywer, vanuit sy kennis en ervaring, sy bronne-materiaal krities moet bestudeer en beoordeel. Bronne is veelkantige en dikwels ingewikkelde groothede wat uiteenlopende gegewens bevat en gewoonlik self bepaal 
word deur motiewe, samehange en lewenshoudings wat inherent in die bronnemateriaal opgesluit lê. Daarom kan dit maklik gebeur dat dokumente verskillende antwoorde gee op die een vraag wat die geskiedenisnavorser stel. Dit beteken dat die agtergrond en die samehange van die dokument baie sorgvuldig nagegaan moet word en teen die getuienis van moontlike ander dokumente afgeweeg moet word. Dit is veral belangrik as primêre bronne soos briewe, dagboeke en herinnerings nagegaan word. 'n Voorbeeld hiervan is byvoorbeeld die vraag na die inhoud van die Gelofte wat die Voortrekkers op 9 Desember 1838 by die Wasbankrivier afgelê het. Daarvoor bestaan daar drie primêre bronne: 'n skrywe van Andries Pretorius van 23 Desember 1838, Jan Bantjes se Journaal van Desember 1838 en Sarel Celliers se herinneringe wat in 1871 opgeteken is. Nie een van dié drie se 'teks' van die Gelofte is dieselfde nie ${ }^{8}$. Dit hang saam met die feit dat die gelofte, so ver vasgestel kan word, nie in daardie tyd op skrif gestel is nie maar alleen mondeling afgelê is. Alleen sorgvuldige en versigtige navorsing met die inagneming van verdere tydgenootlike gegewens kan hier ' $n$ uitkoms gee. Dit is juis by die bestudering van die bronne en die nagaan van die samehange wat deur die materiaal geïmpliseer word, waar die navorser se kundigheid op die proef gestel word. So kan die Gelofte as verskynsel alleen bevredigend verklaar word as die konteks van die Voortrekkers se geloof en teologie ook verstaan word. As dit buite rekening gelaat word, verskraal die rekonstruksie van die verlede-beeld en kan dit skeefgetrek word.

Hier, rondom die Gelofte en sy inhoud, kan die volgende net weer onderstreep word. Die Gelofte is ' $n$ werklikheid wat in die verlede plaasgevind het. Dit is, om dit so te stel, 'n objektiewe werklikheid waaraan die geskiedskrywer niks kan verander nie. Die betrokke Voortrekkerkommando het 'n Gelofte afgelê waaraan 'n bepaalde inhoud gegee is. Aan die waarheid van die gebeure kan nie getwyfel word nie en die gebeure kan nie meer ongedaan gemaak word nie. Die geskiedskrywer kan niks meer doen as om dié gebeure te ontdek nie. Wat hy nou veronderstel is om te doen, is om daardie objektiewe werklikheid in sy samehang te beskryf en te verklaar. Daarom is dit so belangrik om al die fisiese corblyfsels of die nalatenskap of die bronmateriaal wat op die saak betrekking het of kan hê, so sorgvuldig as moontlik na te vors. Dit is wanneer die vraag na vore kom: wat is presies al die ter saaklike feite en getuienis wat die objektiewe werklikheid uit die verlede beskryf of aandui? Dan, ter wille van die verklaring en beskrywing, is die vraag ter sake: wat beteken die inhoud van die bronmateriaal? Dit is hier waar die kritiese waardering van die bronmateriaal deur vergelyking en waardering daarvan, ter sake word. Hier is dit altyd belangrik om die betrokke gebeure in die verlede te verstaan as 'n gebeure wat dár en toe gebeur het en dus alleen verklaar kan word in die konteks van daardie tyd. 
As die Gelofte nou weer na vore gebring word, is dit duidelik dat die definitiewe teks van die Gelofte, soos Sarel Celliers dit op 9 Desember 1838 by die Wasbankrivier in sy gebed geformuleer het, nie meer beskikbaar is nie. Uit die drie primêre bronne, saam met enkele ander herinneringe, kan 'n teks saamgestel word wat na die oorwig van die getuienis, baie naby aan die oorspronklike teks behoort te wees. Die teks sal egter slegs as 'n rekonstruksie aangebied kan word want die oorspronklike het verlore gegaan. Tog kan die rekonstruksie as 'n verantwoorde rekonstruksie beskou word as al die elemente wat volgens die getuienis in die Gelofte voorgekom het, verdiskonteer en opgeneem is.

Verder is dit natuurlik so dat die geskiedskrywer se beoordeling en waardering van die bronne en sy vermoë om daardie bron in sy eie konteks uit te lê, nie gesien kan word as 'n finale rekonstruksie van die verlede nie. Met die vra van ander vrae aan dieselfde bronne of met ' $n$ ander waardering van die bronne kan daar altyd tot 'n ander konstruksie van die geskiedenis gekom word. So gesien is die geskiedenis ofwel die teken van die beeld van die verlede nooit 'n statiese finaliteit nie. Naas die voortgaande speurtog na nuwe bronnemateriaal en saam met die kritiese waardering van die materiaal gekoppel aan die verskillende vrae wat aan die bronne gevra word, word die waarheid vanselfsprekend dat elke geslag sy eie geskiedenis, sy eie beeld van die verlede skrywe. Maar dan bly die voorwaarde onverbiddelik staan dat die rekonstruksie van die verlede, op vaste gronde sal rus, gesteun sal word deur bronnemateriaal ofwel feite wat behoorlik getoets is. Dit gaan immers in die geskiedskrywing om 'n betroubare beeld van die verlede en nie om spekulasie of die legitimering van teorieë wat nie op getoetste bronnemateriaal berus nie. Dit bly waar dat die verhaal van die verlede alleen betroubaar geteken kan word vir sover daar historiese materiaal aanwesig is om daardie verhaal moontlik te maak. Dit gebeur dat die verhaal van die verlede verteken word, soms waar daar ' $n$ minimum aan bronnemateriaal is of daardie materiaal verontagsaam word om juis so opvattings in die hede te wysig in die hoop om die toekoms te beïnloed. Dan is dit egter nie meer geskiedenis nie, nie meer 'n beeld van die verlede nie en val dit in die kategorie van ydele spekulasie of propaganda.

Wanneer die beeld van die verlede, op grond van die nagevorste bronnemateriaal sorgvuldig vasgestel is, dan moet daardie verlede-beeld beskrywe word en sin en betekenis aan die gegewens gegee word. Die samehange, verbande en wisselwerking van die verskillende bewegende kragte in die verlede moet aangedui word, die menslike denke en handelinge beskrywe word binne die bestaande strukture en denksisteme wat daardie periode gekenmerk het. Die maatstaf wat hier aangelê word, is dat die feite wat vasstaan so aangebied word dat dit duidelik is wat feite is, en wat vermoedens is wat aangewend word om verbande te lê wat nie feitelik beskikbaar is nie. Dreyer 
(1974:84) stel dit so: 'Die sinvolle beskrywing is dus waar en dit berus op drie grondpilare: die noukeurige kennis van die verlede, die samehangende beskrywing en die intuitiewe insig in die mens as medemens.' Dit is in hierdie verband waar die vraag na objektiwiteit na vore kom. Ter wille van die oorsigtelikheid word dié saak net aangedui met die volgende': 'Die vraag na objektiwiteit word dus hier nie soseer die vraag na die nakoming van die eise wat die wetenskaplike geskiedskrywing buitendien stel nie, maar dit word die vraag na die voorveronderstellings. Dan moet verder daarmee rekening gehou word dat in die kerkgeskiedenis die voorveronderstelling nie bepaal word deur ' $n$ immanente faktor in die geskiedenis self nie, maar deur die transendente faktor - Jesus Christus, die hoof en heer van die kerk, die dragende middelpunt en die finale einde van die geskiedenis. Dit beteken dat die teologiese gesigspunt waarsonder die kerkgeskiedskrywer nie kerkgeskiedenis kan skrywe nie, met meer duidelikheid en met meer helderheid omlyn moet word sodat die objektiwiteit in die kerkgeskiedskrywing kan toeneem.'

As 'n laaste opmerking oor die skryf van kerkgeskiedenis kan gestel word dat in die kerkgeskiedenis dit vanselfsprekend is dat dit gaan om die gelowige mens én die kerk en dat beide, in hulle wisselwerking met mekaar, na vore moet kom. Dit kan egter nie bly by 'n suiwer saaklike beskrywing nie want dan verskil die kerkgeskiedenis nie, wat sy inhoud betref, van die wêreld se geskiedenis nie. Natuurlik is dit so dat die kerk en die gelowiges in die kerk talle raakvlakke met die verloop van sake in die wêreld rondom die kerk het. Hier kan maar slegs gedink word aan die wisselwerking op die vlakke van die kultuur, die politiek en wat nog meer. Tog is die kerk méér as 'n onderdeel van die geskiedenis van die wêreld of die geskiedenis van die kultuurverskynsels in die wêreld. Dit kan nooit buite berekening gelaat word dat Jesus Christus die lewende hoof van sy liggaam, die kerk, is nie. Hy regeer en lei sy kerk sowel deur Woord en Gees as deur die amp of dienswerk van geroepe gelowiges. Uit die aard van die saak is dit ' $n$ geloofswaarheid wat nie altyd ewe vanselfsprekend of sigbaar is nie ook omdat die mens in die kerk al te dikwels juis daardie werklikheid vergeet of met sy handelinge deurkruis. Maar dit ontneem die kerkgeskiedskrywer nie die verpligting om hierdie aspek in sy beskrywing van die verlede ook na vore te bring nie. Die kerk en sy geskiedenis kan alleen verstaan word as altwee hierdie fasette van die kerk duidelik na vore gebring word 10 .

\section{DIE DUIDING VAN DIE GESKIEDENIS}

Die derde aspek van hierdie bespreking is dan die vraag na die duiding van die geskiedenis. Dit is deesdae, selfs in die kerkgeskiedenis, nie 'n vanselfsprekende saak nie want die algemene opvatting is dat daar nie so iets soos 'n lewende God bo en buite ons 
wêreld en die mens se begripsvermoë kan bestaan nie (Labuschagne 1987:155-6). Omdat die ewige, lewende God nie 'n objek van menslike navorsing kan wees nie, word die kortsluitende gevolgtrekking gemaak dat daar geen God is nie. Dit laat Muller (1969:355-374) konkludeer dat die geskiedenis ook nie na 'n vaste eindpunt beweeg nie. Daarteen neem Berkhof (1958:184-190) 'n ander standpunt in en stel dat aangesien die Skrifte ons leer dat Christus die sin van die geskiedenis is en dat sy terugkeer na hierdie wêreld en die voltooiing daarvan, vasstaan, daarom is dit ook moontlik om in die geskiedenis iets raak te sien van die betekenis of die duiding van die geskiedenis. In die Ou Testament, in die boek Daniël en in die Nuwe Testament in die boek Openbaringe word die koers van die geskiedenis aangedui en al is dit so dat die kerk, die volk van God op pad deur die tyd, dikwels foute gemaak het in sy duiding van die geskiedenis het dit tog 'n blywende aspek van die kerk se geskiedenis gebly.

Vir die kerkgeskiedskrywer is die saak van die duiding van die geskiedenis een van die moeilike aspekte van die kerkgeskiedskrywing. Enersyds is daar die feitlikheid van die voorsienigheid van God, die almagtige wat oor sy skepping regeer. Andersyds is daar die mens en die kerk wat in verantwoordelikheid hulle weg deur die wêreld en die tyd gaan. Sonder om hierdie dialektiese verhouding volledig te behandel, is dit tog so dat die gelowige en die kerk betrokke is by sowel die voortgang van die koninkryk van God deur die wêreld as die weerstand daarteen deur die anti-goddelike magte. Hoewel dit nie altyd maklik is om dit volledig en trefseker raak te vat nie is dit ook so dat die kerkgeskiedskrywer in sy tyd en op sy plek tog soveel insig kan bekom as wat God hom wil gee en wat volgens die oordeel van God vir hom genoeg is (Barth 1950:2329). Daarby is dit ook waar dat die kerkgeskiedskrywer se beoordeling en duiding van die geskiedenis betreklik is. Beoordeling en duiding hang egter saam met wat genoem kan word die verstaan van die geskiedenis. Elton (1967:66) stel dit so: 'The task of history is (primarily) to understand the past, and if the past is to be understood it must be given full respect in its own right. And unless it is properly understood, any use of it in the present must be suspect and can be dangerous. One cannot use a corrupt means to a worthy end.' Dit het, uiteindelik, tog meer sin om vanuit die geloof ' $n$ duidelike woord te spreek as om te swyg en die indruk te skep dat die kerkgeskiedenis 'n suiwer menslike aangeleentheid is. Vanuit die geloof moet die tekens van die heerskappy van Christus asook die anti-goddelikke tendense aangedui word. Alleen so, al is dit gebrekkig, sal die sin van die geskiedenis duidelik word en elkeen weer versterk word in die geloof dat die kerk geroep is om saam te werk aan die deurwerking van die koninkryk van God in die tyd. So kan die kerkgeskiedskrywing bydra dat die geloof van die kerk in die hede versterk word en die kerk as volk van God, deur die tyd, op koers bly na die finale voltooiing en die heerlikheid. 


\section{SLOTOPMERKINGS}

By die nalees, navorsing en nadink oor die kerkgeskiedenis en die skrywe daarvan is dit tog opvallend dat die geskiedenis van die kerk, veral vanaf die tyd van die Kerkhervorming, altyd 'n eie plek in die lewe en die teologie van die kerk gehad het (Berger 1955:23-24, \& Meinhold 1967:227). Dit ook omdat die kerk rus op die openbaring van God in die tyd. Vir die kerk én sy teologie is dit so dat die kennis van die geskiedenis onontbeerlik is as die kerk wil leef as 'n voortsetting van sy eie geskiedenis. Dit is één les wat die reformatoriese vadere ons geleer het. Die kerkgeskiedenis bly belangrik nie omdat die geskiedenis en God se handele wat daarin opgemerk kan word as 'n bron van 'n voortgaande openbaring geld nie, maar omdat dit die geskiedenis van God se volk is wat op pad is na die voltooiing en die wederkoms van Christus.

Dit is vanjaar veertig jaar gelede dat ek die eerste maal agter die akademiese kateder 'n staanplekkie gekry het. By 'n terugblik op dié tyd is daar 'n gevoel van dankbaarheid dat ek so lank besig kon bly met 'n taak ten behoewe van die kerk en sy opleiding en wat aan my die geleentheid gegee het om ook 'n bydrae te maak tot die kennis van die geskiedenis van die kerk. As daar dan van my werk bruikbaar is, dan is dit seker in die eerste plek te danke aan die Here van die kerk wat dit bruikbaar gemaak het tot opbou van die kerk. 'n Bron van persoonlike voldoening is dat deur die jare daar manne na vore gekom het wat wou deel in hierdie taak van navorsing en skrywe van kerkgeskiedenis. Dit is my oortuiging dat hulle nou al en in die toekoms hierdie taak met toewyding en onderskeiding verder sal voer.

Die studie van die gister van die kerk bly 'n voortgaande opdrag vir die gelowiges en die kerk. Dit is en bly ' $n$ veeleisende taak maar is terselfdertyd 'n opdrag wat sy beloning saam met hom bring.

\section{Endnotas}

1 In hierdie verband kan die omvangryke, tweedelige werk van P Meinhold 1967, Geschichte der Kirchlichen Historiographie, Freiburg - München: Verlag Karl Alber nagelees word. Dan ook die belangwekkende werk van P S Dreyer 1974, Inleiding tot die filosofie van die geskiedenis, Kaapstad-Pretoria: HAUM. In verskillende artikels is, oor die jare, die vrae en probleme van die geskiedskrywing al gepeil en nader bespreek. Tog is daar nie veel aandag aan die besondere vereistes van die kerkgeskiedenis gegee nie. Vergelyk in hierdie verband C F A Borchardt en W S Vorster (reds) 1980, SA Teologiese Bibliografie, Pretoria: UNISA, Deel 1, 141-142 en Deel 2, 74-77.

2 Vergelyk hier P S Dreyer 1974:29-46. Selfs R Bultmann 1957, History and eschatology, Edinburgh: The University Press, 110-137 moes swoeg om 'n pad tussen al die omskrywings te vind. Dit is seker nie nodig geag om hier 'n lang literatuurlys te gee nie want dié kan maklik elders gevind word. 
3 Vergelyk hier K D Schmidt 1954, Grundriss der Kirchengeschichte. Göttingen: Vandenhoeck \& Ruprecht, 1-2. Sy argument is dat hoewel in Handelinge die werksame faktor God, die Heilige Gees, is dit tog die Gees van die Here waarvan daar sprake is vergelyk Handelinge 5:3-9.

4 H Berkhof 1958, Christus de zin der geschiedenis. Nijkerk: C F Callenbach N V, 82-83. Daar kan op gewys word dat daar 'n groot afstand is tussen hierdie stelling van Berkhof en sy opmerkings in 1969 wanneer hy, skynbaar haastig omdat die wêreld so stadig verander, die hulp van die marxisme inroep. Daardie 'ideology of change', soos hy dit noem, word dan deur hom tipeer as die middel by uitstek om die ideaal van vernuwing nou te bereik. Die wederkoms lê dan skynbaar te ver vorentoe! Hierin is daar ook 'n stuk tragiek want met die verandering van die inhoud van die prediking van die regte verkondiging van die Woord van God na die propagering van horisontale, marxistiese doelwitte is in Nederland in 'n periode van ongeveer vier dekades die gelowiges uit die kerk uitgepreek en het die kerkgeboue museums en sekulêre vergaderplekke geword omdat daar nie meer 'n gemeente is nie.

5 Die opvatting leef ook in die Rooms-katolieke teologie waar die kerk 'n sterk aksent as die mistieke liggaam van Christus dra. C Davis 1996, God's grace in history. London: Collins, 75 stel: 'Nevertheless, Christ is the Lord of history. Despite sin He is directing human history as a whole to the final Kingdom. Yet it remains true that the historical process is a working out of God's plan and a progress towards the Kingdom. God's plan which is operative through grace, embraces the whole of history, not just the part directly related to the Chruch. The world outside the Church includes an achievement of Christ.' Hoewel daar oor die besonderhede van sy argument verskil kan word, byvoorbeeld dat dit 'n vraag is of die Rooms-katolieke verstaan van genade die manier is waarop God die geskiedenis rig, bly dit staan dat sy argument in die bree geldig is.

6 In hierdie verband kan gelet word op die argument wat Joh Calvyn voer in sy pamflet van 1545. Contre la secte phantastique et furieuse des Libertins. Qui se nomment spirituelz, OC 7, 145-248. Hier stel Calvyn dat God nie deur 'n mens werk asof hy 'n willose stuk hout is nie, maar die mens as 'n redelike skepsel behandel soos Hy die mens geskep het. Daarom is dit nodig om onderskeid te maak tussen die bedoeling wat die mens het wat 'n bepaalde saak nastreef en God se oogmerk. Die twee sake kan grootliks verskil en omdat die mens 'n sondaar is, is dit gewoonlik ook die geval. Daarom is die toestand in die wêreld nie God se skuld nie maar die gevolg van die sonde van die mens. Terwyl dit so is, is daar ruimte vir die oproep dat die mens hom diensbaar aan God sal maak. Terselfdertyd kan kennis geneem word van die stelling van P S Dreyer 1974:247: 'Die Christelike beskouing maak die mens juis radikaal vry en verantwoordelik sodat die dinamiek van die geskiedenis, die voortdurende verandering nie verder gesoek hoef te word as in die aard, die doen en late van die mens self nie. In die Christelike beskouing bepaal God wel die geskiedenis maar nie op so 'n wyse dat God op enige wyse die mens sy verantwoordelikheid ontneem nie.'

7 Die saak word hier nie verder geneem nie, ook omdat Dreyer (1974:119-214) die saak uitvoerig bespreek. Miskien is dit tog belangrik om juis hier kennis te neem van die opvatting van Herbert J Muller 1969, The uses of the past. Profiles of former societies. London: OUP, p 40: 'One may 
reasonably argue that Christ is the most nearly perfect symbol of the one God that all the higher religions have sought to comprehend. One cannot reasonably take for granted the certain truth of an exclusive divine revelation. A revelation that was granted to an obscure group at a particular moment in history, that was recorded by fallible men in narrative marked by manifest inconsistencies that cannot be proved by independent reason, and that Christians themselves have never been able to agree upon, much less to embody in a Christian society .... This religious selfrighteousness is both cause and simptom of a general cultural chauvinism.' Hierdie soort opmerking is nogal tiperend wanneer die menslike rede (en dan veral dié van die skrywer) die laaste en finale maatstaf word om die geskiedenis te verstaan. Hierdie benadering is natuurlik so oud soos die bestaan van die Christelike geloof en selfs die apostel Paulus het hom al daarteen verweer vergelyk 1 Korintiërs 1:17-31. In ons dae waar bowendien net 'n geslote wêreld geken word en selfs die wetenskaplike sosialisme as 'wetenskaplik' erken word, is die waarheid van die unieke openbaring van God in Jesus Christus in die spervuur van die ongeloof ó́k in die kerklike wêreld. Vergelyk Martin A Larson 1989, The Essene-Christian Faith, Costa Mesa Calif: The Noontide Press; C F Potter 1992, The lost years of Jesus revealed, New York: Ballantine Books; M Baigent and R Leigh 1992, The Dead Sea scrolls deception, London: Transworld Publishers.

8 Vergelyk E P Büchner 1993, 'n Dankdag soos 'n Sabbat, ongepubliseerde MTh-verhandeling Universiteit van die Oranje Vrystaat, 33-36 asook A D Pont 1986, Die gelofte in gedrang in F J Strauss 1986, Bloedrivier, Windhoek: Eros Uitgewers 16-23. Die problematisering van die 'teks' van die gelofte dateer uit 'n tyd toe die viering van Geloftedag, soos dit tradisioneel geskied het, 'n politieke verleentheid geword het in die aanloop na 1994. Dit is nogal 'n mooi voorbeeld van hoe die stem van die verlede 'gebruik' is om 'n ander verlede-beeld in die hede te skep om sodoende die toekoms van Geloftedag te verander.

9 A D Pont 1963, Enkele opmerkings oor objektiewe kerkgeskiedskrywing, artikel in $H T S / 18$, 146-153. Die aanhaling kom voor op p 152. P S Dreyer 1974:84-96 beredeneer die saak uitvoerig sodat dit nie nodig is om hier verder daarop in te gaan nie.

10 In hierdie verband W Nigg 1934, Die Kirchengeschichtsschreibung: Grundzuge ihrer Historischen Entwicklung, München: C H Beck'sche Verlagsbuchhandlung, p 255: 'Die Kirche hat somit zwei Dimensionen. Sie besitzt eine immanente und eine transzendente Seite. Fur die Kirchengeschichtsschreibung sind beide Seiten von Bedeutung. Es geht nicht an, eine Seite vollständig ausser acht zu lassen. Sowohl die immanente als auch die transzendente Seite muss berucksichtig werden, dieweil nur beide zusammen eine vollständige Kirchengeschichtsdarstellung ausmachen.'

\section{Literatuurlys}

Baigent, M \& Leigh, R 1992. The Dead Sea scrolls deception. London: Transworld Publishers.

Barth, K 1950. Kirchliche Dogmatik III/3, Zollikon-Zürich: Evangelischer Verlag A G.

Berger, H 1955. Calvins Geschichtsauffassung. Zürich: Zwingli Verlag. 
Berkhof, H 1958. Christus de zin der geschiedenis. Nijkerk: G F Callenbach.

Büchner, E P 1993. 'n Dankdag soos 'n sabbat. Ongepubliseerde MTh-verhandeling, Universiteit van die Oranje Vrystaat.

Bultmann, R 1957. History and eschatology. Edinburgh: The University Press.

Calvin, J 1545. Contre la secte phantastique opgeneem in Baum, G, Cunitz, E, Reuss, E (eds) 1863-1900. Ioannis Calvini opera quae supersunt onmia. Brunsvigae: G A Schwetschke et filium (aangehaal as $\mathrm{CO}$ ).

Davis, C 1966. God's grace in history. London: Collins.

Dreyer, P S 1974. Inleiding tot die filosofie van die geskiedenis. Kaapstad-Pretoria: HAUM.

Elton, G R 1967. The practice of history. London: Fontana Library.

Labuschagne, J P 1987. Die historiese konteks van die 20ste eeuse samelewingsteologieè. DD-proefskrif, Universiteit van Pretoria.

Larsson, M A 1989. The Essene-Christian faith. Cosa Mesa California: The Noontide Press.

Meinhold, P 1967. Geschichte der Kirchliche Historiographie. Freiburg-München: Verlag Karl Alber.

Muller, H J 1969. The uses of the past. London: OUP.

Nighg, W 1934. Die Kirchengeschichtsschreibung. München: C H Beck'sche Verlagsbuchhandlung.

Pont, A D 1958. Die geskiedenis van die Christendom. HTS/13, 2-8.

1963. Enkele opmerkings oor objektiewe kerkgeskiedskrywing. HTS/18, 146153.

Potter, C F 1992. The lost years of Jesus revealed. New York: Ballantine Books. 